\title{
Mira Wilkins
}

\section{The History of Multinationals: A 2015 View}

$\mathrm{M}$ ore than forty years ago (in the autumn of 1974), Business History Review had a special issue on multinational enterprise (MNE). With two exceptions, the authors in this new special issue were not yet born or were toddlers when that issue was published. Whereas in 1974 relatively few individuals were writing on topics directly related to the history of multinational enterprise, in 2015 numerous authors are considering subjects that fall under this rubric. Still, by the mid-1970s the study of the history of multinationals was not virgin territory. Glenn Porter, then editor of Business History Review, wrote in a preface to the 1974 issue, "Most of the contributions here underscore the deep historical roots of multinational business and point to the importance of an awareness of the past in understanding the present."

As an introduction to this present issue, it seems appropriate to compare the two special issues of $B H R$ and reflect on how scholarship on this subject has changed over the decades. Porter pointed out that the 1974 issue was distinctive in that "most of the articles deal with enterprises based outside the United States." That insight was important, for the earlier literature had focused mainly on the history of U.S. multinational enterprises. However, U.S. multinationals were not totally neglected in the 1974 issue. American multinationals had expanded greatly in the twenty-five years after World War II. They had been the topic of multiple studies, but by the early 1970 s there had been a shift in thinking about the subject. New attention had been given to multinationals from Europe and their long histories and to Japanese multinationals and their storylines.

What is evident to me as I look back at that 1974 special issue is the strong impact that Harvard Business School's Raymond Vernon had on the contributors. Vernon had undertaken a major project at Harvard Business School (HBS) that dealt with the foreign operations of the world's largest manufacturing companies; phase 1 had dealt with U.S. business abroad, phase 2 (in process in 1974) with non-U.S. multinationals. Larry Franko, who wrote in the 1974 issue on the origins of multinational manufacturing by continental European firms; John Stopford, whose subject was the origins of British-based multinational 


\section{Mira Wilkins / 406}

manufacturing enterprises; and Mike Yoshino, who described the spread of Japanese manufacturing multinationals after World War II, were all students of Vernon. Their articles had their genesis in phase 2 of Vernon's massive HBS project on non-U.S. multinational enterprises. Vernon's project focused on contemporary multinational enterprise, but he was interested in history and pushed his students to pay attention to and collect information on the history of the major manufacturing firms that he was studying.

Vernon was a giant in research on multinational enterprise; his influence was widespread among American students of the subject who dealt with both contemporary and historical aspects of multinational enterprise. In the early 1970s, across the Atlantic, John Dunning (having moved to the University of Reading) had been publishing on multinational enterprises and their histories. While Vernon had created a hub for multinational enterprise activities at HBS, Dunning set up another center at Reading. At that point, Dunning was already well known but still had little influence on the authors contributing to the 1974 Business History Review special issue. Subsequently, his influence on many of these individuals, and others, would be profound.

The 1974 special issue included articles by John P. McKay and Charles Kindleberger. In 1970, McKay had published the prizewinning volume Pioneers for Profit: Foreign Entrepreneurship and Russian Industrialization, 1885-1913. When his BHR article, entitled "Foreign Enterprise in Russian and Soviet Industry: A Long-Term Perspective," was published, he was listed as an associate professor of history at the University of Illinois, Urbana. He saw himself as a specialist in European economic and social history. The MIT economist/ economic historian Kindleberger provided an article for the 1974 issue on the origins of U.S. direct investment in France, based on a paper he had presented at a conference of the French Association of Economic Historians. Along with his many valuable writings in economic history, Kindleberger had published a set of lectures in 1969 titled American Business Abroad: Six Lectures on Direct Investment; its first chapter was "The Theory of Direct Investment." In that book, Kindleberger introduced his readers to the 1960 (then unpublished) dissertation of Stephen Hymer, who had argued that "direct investment belongs more to the theory of industrial organization than to the theory of capital movements." (Hymer's thesis would not be published until 1976, after his death in a car accident in February 1974; Kindleberger arranged for its publication). ${ }^{1}$ And I, too, contributed to this 1974 special issue. My

\footnotetext{
${ }^{1}$ Kindleberger did not realize until a number of years later that his 1969 book shared the same primary title as my 1964 one!
} 
book The Emergence of Multinational Enterprise: American Business Abroad from the Colonial Era to 1914 had been published in 1970, and The Maturing of Multinational Enterprise: American Business Abroad from 1914 to 1970 was published that year (1974), both by Harvard University Press. My contribution to the 1974 issue of $B H R-$ a spin-off from research I had done for The Maturing-was entitled "Multinational Oil Companies in South America in the 1920s: Argentina, Bolivia, Brazil, Chile, Colombia, Ecuador, and Peru.” The abstract stated, "The author throws light on the development of business-government relations in that part of the world [South America], where the hostility of host nations to multinational enterprises was to grow so strong."

I knew all the contributors to the 1974 issue. Ray Vernon had had a great influence not only on his students Larry Franko, John Stopford, and Mike Yoshino, but on yours truly as well. I had met him not long after I had published my first book, American Business Abroad: Ford on Six Continents (1964), when I was at Columbia Business School working on a general history of American business abroad. He had been very supportive of my career. Kindleberger's work I knew well, but I knew him less well on a personal level. In 1978 he agreed to serve on the advisory board of my Arno Press reprint series on international finance, and in 1983, both he and Vernon served as advisers for my Garland Press reprint series on the world economy. At the time of the $B H R$ special issue, in 1974, Alfred Chandler's work on the history of American business was having an influence on me, but not yet on the issue's other contributors. Chandler was newly installed at HBS and had hired Glenn Porter, who was editor of the BHR and Chandler's student. Indeed, Chandler may well have encouraged the publication of the 1974 issue.

Contributors to the $B H R$ issue came from business schools, history departments, and economics departments. While all the contributors were based in the United States at the time they were writing their articles (although not necessarily at the time the issue was published), all had internationally oriented backgrounds. Franko, who had been trained by Ray Vernon, was listed as being at the Centre d'Études Industrielles, Geneva. British-born Stopford had returned to England and was, at the time of publication, professor of international business at the London Graduate School of Business Studies. Kindleberger and McKay were known for their work on European economic history. All six of the contributors were comfortable with international travel. The first jets had crossed the Atlantic within their adult lifetimes, in 1958. Unlike most Americans in 1974, all had passports and all had been to and traveled in Europe. Mike Yoshino (who was born in Japan) and I had traveled in Japan. I think I was probably the only contributor who 


\section{Mira Wilkins / 408}

had traveled to and through Latin America (and Africa) at that point in time.

Although Vernon, Kindleberger, and I had all thought about (and had written about) "theory," and although all the contributors were au courant in what were the newly emerging theories of multinational enterprise, Vernon's student contributors for the most part gave a straight narrative on the origins of MNEs of the various countries, with little reference to theory per se. Kindleberger's paper was descriptive. As for me, the problem I was trying to deal with was the relationship between various corporate functions within oil companies and U.S. and host government concerns. My questions did not involve reference to MNE "theory." And John McKay, a historian (1968 PhD, Berkeley), was interested in accurately portraying events that had occurred rather than abstracting theoretical constructs.

In the period between 1974, when the first special issue on MNEs was published, and now, much has changed in the actualities of the history of multinationals as well as in treatments of the subject. The period from 1974 to the present-itself now part of history-saw a vast expansion of MNEs along with an expansion of the literature on MNEs and their history.

Fast-forward to 2015: the history of multinationals has been the subject of numerous articles, books, case studies, and anthologies. I have written a great deal on this topic, as has Geoffrey Jones, and we have been joined by many others in the process of trying to document and explain the course of multinational enterprise behavior over time, the nature of multinationals, theories of multinationals, multinationals in specific home and host countries and in specific industries, and the overall impacts of multinationals. With ebbs and flows, before and after 1974, students of the history of multinationals discussed the role of technology in giving multinationals advantage, what advantage meant, and why and how companies succeeded (or failed). They (we) have explored topics ranging from political risk, intellectual property, and cartelization to MNEs and beauty. The subject has been a subtext (sometimes elaborated on, sometimes covered merely in passing) in histories of the world economy, histories of capitalism, international economics and international trade textbooks, the economic development literature, the marketing and management literature, and financial histories. Students of the pharmaceutical industry combined medical history and business history. Literature from law professors on, for example, the histories of regulation, taxation, and corporate structures as well as "conditions of doing business" often include valuable data on the history of multinationals. Scholars in fields from sociology to geography have provided insights on the history of multinationals. 
Students of "foreign investment" dealt with (and separated out) the histories of multinational enterprise within that broad subject. These are but a sample of the wide-ranging interests. In many ways over the years, as business history has become increasingly interdisciplinary, students of the history of multinational enterprise were in the vanguard (or perhaps should have been).

Actually, not enough has been done. There were (and are still) many gaps. The general and multiple roles of the multinational still need to be defined and understood. Too many relevant studies ignored or minimized the importance of the historical role of multinational enterprise. Thus, a collection such as the one in this 2015 issue of $B H R$ is extremely welcome.

Where then do the five contributions to this current issue fit into the literature? How does this 2015 issue compare with that of 1974? What do these 2015 articles add to the existing literature? What distinguishes them not only from the 1974 contributions but from the multitude of writings published between 1974 and 2015?

The principal influences on these authors are different from those on the contributors to the 1974 issue. Most of the authors in this 2015 collection have been influenced by Geoffrey Jones and John Dunning ("the Reading school"), along with a whole generation of worthy contributors to the theory, practice, and history of multinational enterprise. Jones was at Reading for twelve years before he arrived at HBS almost a decade and a half ago. The faculty at the University of Reading Business School (now the Henley Business School) has had an exceptional impact on research on the history of MNEs. This was not reflected in the 1974 special issue, but it is clear in the 2015 special issue.

One is immediately aware that the articles in the current special issue, compared to those published in 1974, focus less on "origins" than on seeking to understand the ongoing activities of MNEs. Although Donzé's article deals with "entry," it is the entry (re-entry after World War II) of a well-established firm, and the framework for the entry is set within past (as well as contemporary) constraints. All of the 2015 articles deal with the twentieth century, although all of them consider (or at least mention) companies that date back to the nineteenth century: the predecessor to HSBC, Tata, Concha y Toro (Verbeke and Kano); Siemens (Donzé); Havas, Wolff, Reuters (Tworek); Bayer, Hoechst, BASF (Lubinski); and Singer (De la Cruz-Fernández). Some of the authors bring their subjects into the twenty-first century, emphasizing, much as Glenn Porter did in 1974, that we can learn from the past.

None of the 1974 articles dealt with theory per se. This new collection leads off with Alain Verbeke and Liena Kano's essay, which poses the question as to whether the "new internalization theory" is applicable to 
the many MNEs that have their head office in emerging nations, or whether a new theory is needed. Verbeke and Kano believe that the "dominant paradigm" in international business today is the new internalization theory. They summarize the key features of this theory and show how it can be used in analyzing the strategies of multinationals based in emerging-economy home countries. In 1974, there did exist some multinationals headquartered in emerging nations, as Verbeke and Kano point out; they were not, however, sufficiently prevalent to prompt discussion in the 1974 special issue. Now the topic has become relevant. To test their approach, Verbeke and Kano explore some of the overall historical approaches to MNEs. They also use as a point of departure today's "world-class emerging multinationals" and single out ten on which business school case studies have been done. After testing the new internalization theory against the available evidence, the authors conclude that, yes, the new internalization theory is applicable to emerging-economy MNEs and there is no need for a new theory. Interestingly, they address their article to two separate audiences: the international business scholars in the business schools (hoping to show how history matters to understanding) and the historians (aiming to demonstrate that theory-not just any theory, but the new internalization theory-aids in understanding). All business historians, whether in business schools or in history departments, will find this article pushes its readers to ask what is important to the understanding of the MNE, what is meant by "firm-specific advantages," and where "countryspecific advantages" fit.

Pierre-Yves Donzé considers the activities of a Siemens affiliate in the construction of hospitals in Latin America in the 1950s and 1960s; as he does so, he asks, Do these activities conform to the theoretical approach of Dunning's OLI (ownership-location-internalization) theory, and what about other theoretical frameworks? Drawing on the work of Vernon and Edith Penrose, Donzé tries to combine a "business history approach" as he perceives it with a medical history approach. What is new about his analysis is his specific topic (his evidence from the Siemens archives-see below). Ultimately he casts off the fetters of "the classical pattern of MNE," using his archives-generated evidence successfully.

In a quite different manner, but also attempting to be guided by theory, Heidi Tworek explores-in the context of political and economic news-Arrow's paradox: that customers can only determine the value of information they would like to purchase when they see that information, though once they see (have) the no-longer-secret information it loses its value. Tworek's use of theory here, like Donzé's, does not search out a comprehensive argument, but rather pulls out theoretic insights to 
gain understanding of the narrative. It is a rather separate use of theory from that of Verbeke and Kano, but once again shows the insights that can be gained by asking different questions of historical materials. Theory pushes the historian of multinational enterprise to ask questions that would not otherwise have been asked.

Increasingly, today, explicitly as well as implicitly, many (but far from all) students of the history of multinationals seek to draw on "theory," and "theories," to aid in explaining the behavior of multinational enterprise. And, indeed, since 1974, many theories and theoretical constructs have emerged that can greatly enrich our understanding. The articles in this issue (especially those by Verbeke and Kano, Donzé, and Tworek) reflect such interests in joining theory with history.

The scope and breadth of this current issue is more comprehensive than were those of the 1974 issue. I think this reflects a new understanding of the multifaceted aspects of MNEs. Thus, Donzé's article on Siemens is not simply an account of a German manufacturing multinational enterprise with a firm-specific advantage in medical equipment; rather, Donzé pushes us to recognize the varieties of MNE behavior within a giant enterprise. This is a story of the construction and engineering in Latin America (and globally) of hospitals by an affiliate of a large, longstanding German manufacturing multinational, Siemens. In the 1950 and 1960s, in order to sell medical equipment in Latin America, Siemens moved into the construction of fully equipped hospitals. Donzé tells a complex story about the nature of project management, about competition, and about antimonopoly concerns. He successfully tells of Deutsche Hospitalia, an informal association of thirty German firms set up in 1949, and Hospitalia International $\mathrm{GmbH}$, created from a merger of firms in 1964. Donzé's consideration of health care and hospitals in Latin America (and then farther afield) in the context of the history and spread of multinational enterprise is highly valuable. His work is based on careful research in the very rich Siemens archives. This is the third of three articles Donzé has published between 2013 and 2015 on the history of Siemens's international business in the medical field; all three are truly original and cover materials that are available nowhere else. His work fills a clear gap in our knowledge.

Two other articles in this 2015 issue are, like Donzé's, on German MNEs. Tworek's article on German businesses is distinctive in its choice of industries. Multinationals in the news business have not been adequately studied. Tworek opens up new horizons when she differentiates (in the histories of two German firms) the business organization of political and economic news. Like Donzé, she is expanding the field of the history of multinational industries to deal with different kinds of markets. She covers regulation and its nature and breaks new 
ground as she explores, based on archival resources, the business history of Transocean and Eildienst. Are news agencies a type of public utility? Tworek considers this interesting thought as she explores the histories of these news agencies. Her article suggests the need for a follow-up book on the history of news agencies, and not only the two German ones. Tworek's research is novel.

The third article on German business abroad comes from Christina Lubinski, and what a revealing article it is. The literature on the history of MNEs (albeit not including the 1974 BHR issue) has had a segment that deals with imperial reach; it considers British investments in the British Empire, French investments in the French Empire, Dutch investments in the Dutch Empire, and so forth. Lubinski is interested in a set of German businesses (the principal German dye producers) and their experiences in British India. Within the empire, India was a developing country that was a large market for the German dyestuff producers. Unlike others who have studied these dye makers in the United States and more broadly, Lubinski looks at these advanced technology firms within British India-a neglected topic. She documents the experiences from the late nineteenth century to the outbreak of World War II and beyond, dealing with the German businesses (and the various intermediaries that represented them) through the political travails of wars, nationalism, and boycotts. Her work adds importantly to our realization that it is far too narrow an assumption that only British businesses operated in the British Empire. Multinational enterprises of other nationalities played a role and that role comes across well in the story that Lubinski tells. The material is unique, put in context, and, to this commentator, entirely plausible. Lubinski argues that in India, being "foreign" (i.e., not British) was often an advantage for these (and other) German businesses and their Dutch representatives.

This current issue differs from the 1974 issue in its new emphasis on emerging countries not only as home to multinational enterprise (in Verbeke and Kano's article) but also as hosts (in the articles by Donzé; Tworek, to some extent; Lubinski; and De la Cruz-Fernández). To be sure, the authors in 1974 did not ignore emerging nations as hosts: Yoshino pointed out that Japanese manufacturing investments overseas in the early 1970 sere principally in developing countries (some 85 percent), Stopford dealt with British firms in both developed and less developed hosts, and my article was on oil companies in developing countries in South America in the 1920s. A general survey of the literature in 1974 would have found much more, on agriculture, mining, and oil. All five articles in the present issue touch on, and four are devoted to, topics related to emerging nations. 
This brings me to Paula de la Cruz-Fernández's article on the U.S. multinational enterprise Singer Sewing Machine, in Mexico, from its origins there in the late nineteenth century to the late 1930s, with an emphasis on the 1920 s and 1930s. Her piece is on how the Singer firm reached Mexican consumers through a well-developed marketing network that used practices from other Singer operations abroad but fashioned them to Mexican conditions. The Mexican Revolution (roughly 1910 to 1920) curbed the company's business as travel in many parts of Mexico became dangerous. De la Cruz-Fernández tells us that by the 1920 and 1930s, however, Singer's Mexican business had more than recovered, and within the company, its marketing methods in Mexico were considered exemplars for Singer in New York and London, to be passed on to other operations around the world. Her article introduces a distinctive focus to the literature on the history of multinational enterprise. In contrast to the thrust of all the 1974 special issue articles and all the other articles in this issue, this article is concerned with what happens to the end consumer (that is, the female consumer). De la Cruz-Fernández's interest (and Singer's) is (was) in "home sewing." She has effectively combined a background in gender studies with her knowledge of the way multinationals operate in markets abroad. Singer shaped the lives of women throughout Mexico and was, in turn, shaped by these principal customers, Mexican women. Sewing is a very basic activity, and we forget in our present era of ready-made garments how important the actual sewing of garments was to world history. De la Cruz-Fernández puts the business history of Singer in the context of modern Mexico and the modern Mexican woman. Nothing in the 1974 collection of essays shared her approach. Hers is an original contribution on Singer's reciprocal impact on Mexican history and how the firm's business was influenced by Mexican history and culture.

As I compared the two special issues, of 1974 and 2015, I was going to add that the 1974 one emphasized manufacturing multinationals, while the 2015 issue shows more variety in sectors, in industries, by multinational enterprises. Yet the breadth of interest in the differences in types of multinationals and their investments was already evident in the 1974 issue, in Kindleberger's discussion of the history of American multinationals in France, which included finance, insurance, trade, oil, and general services. Clearly, however, Donzés Siemens article on hospital construction and Tworek's piece on news agencies look at industries not considered in the 1974 issue, while De la Cruz-Fernández's discussion of the organization of Singer's marketing has no counterpart in that previous collection. 
The contributors to the 1974 issue came from business schools, history departments, and economics departments. In 2015, the contributors come from business schools and history departments, albeit there are traces in some articles of the impact of what is emerging in the economics literature. Between 1974 and today, students of MNEs in a number of business schools have had faculty interested in the history of multinational enterprises. So, too, those trained in history departments have within that framework and in business schools contributed a body of knowledge. As for economics departments, few young people today are interested in the history of multinational enterprise, and those who are interested, those trained in economics, have tended to migrate to business schools. This special issue reflects the fact that (with few exceptions) business schools and history departments are currently the homes to faculty wanting to study the history of multinational enterprise.

Despite the international involvements of the 1974 group of authors, the contributors to this 2015 issue seem to have even broader crossborder backgrounds. Today, students of the history of international business think nothing of international travel; after all, they have grown up taking jet travel for granted. Few places are "exotic." They see nothing odd about teaching at universities in countries other than their place of birth. In fact, their academic appointments range from Copenhagen to Calgary to Osaka. This also shows up in the topics that interest them, topics that are global in nature. By my estimate, of the six contributors to the 1974 issue, two were born outside the United States. Of the six contributors to this issue, all were born outside the United States.

In sum, the collection of articles on the history of MNEs in this special issue brings into view the ideas of a new generation of scholars. Each of these articles introduces the reader to new books and articles, new approaches to the history of MNEs, and a wide range of new insights. The issue contributes greatly to showing how varied and fruitful are the current range of inquiries. Clearly, research on the history of MNEs is alive and well. Walter Friedman and Geoffrey Jones are to be congratulated for publishing these thought-provoking original articles.

MIRA WILKINS is professor emeritus of economics, Florida International University. 